\title{
The Effects of Social Media, Email Marketing, Website, Mobile Applications Towards Purchase Intention - Consumer Decisions
}

\author{
Natasha \\ Communication Department, BINUS \\ Graduate Program, Master of Strategic \\ Marketing Communications \\ Bina Nusantara University \\ Jakarta, Indonesia \\ natashaclaudia.nc@gmail.com
}

\author{
Zunvindri \\ Communication Department, BINUS \\ Graduate Program, Master of Strategic \\ Marketing Communications \\ Bina Nusantara University \\ Jakarta, Indonesia \\ zunvindritaniaty@gmail.com
}

\author{
Edi Abdurachman \\ Communication Department, BINUS \\ Graduate Program, Master of Strategic \\ Marketing Communications \\ Bina Nusantara University \\ Jakarta, Indonesia \\ edia@binus.edu
}

\begin{abstract}
This study is to understand the effects of digital marketing towards purchase intention that creates consumer decision. Digital marketing strategies that being used in this research consist of email marketing, website, mobile application and social media. Digital marketing is proven to have $71.74 \%$ of effect towards purchase intention. Social media (p-value: 0.0004$)$ $\&$ website (p-value: 0.0017) are the most effective digital marketing strategies, while newsletter and mobile application don't bring that same effect. Purchase intention is also proven to have effect of $63.18 \%$ towards consumer decision.
\end{abstract}

Keywords: Digital Marketing; Purchase Intention; Consumer Decision

\section{INTRODUCTION}

The global MICE industry is set to reach $\$ 1.245$ billion in 2023, according to the new "MICE Industry by Event Type: Global Opportunity Analysis and Industry Forecast, 20172013" report by Allied Market Research. With the MICE industry being valued at $\$ 752$ billion in 2016 , that would represent a growth rate of 7.5 percent from 2017 to 2023 [1].

Based on region, Asia-Pacific is expected to witness the highest growth rate of 8.6 percent during the forecast period. This region is significantly driven by emerging countries such as Singapore, China, and India. Moreover, ease of visa restrictions, investments in better infrastructure, and high demand in commercial aviation further fuel the growth of the Asia-Pacific MICE industry (2017) [1].

Indonesia MICE industry has risen drastically in the past few years. Ismaya as the market leader in Indonesia has shown a lot marketing activity to boost up the growth. Ismaya Live is the live event division of Indonesia's leading lifestyle company Ismaya Group. Established in 2011, the passionate team of Ismaya Live aim to bring an all-rounded event experience with world-class productions and unique concepts

The team have broken records and set a whole new bar in the live event industry in the region with festivals such as Djakarta Warehouse Project that has now become one of the biggest dance music festivals in Asia; We The Fest, an allages multi-genre festival experience showcasing music, arts, fashion, and food; Jakarta Culinary Feastival, the biggest experiential culinary festival in the capital; Ultra Beach Bali, the first beachfront Ultra event in the world; Sunny Side Up Tropical Festival, a boutique summer music festival on the
Island of the Gods, Bali; and ON OFF Festival, a brand new festival that showcases and translates everyone's online cravings into a unique offline experience.

According to Kotler, marketing mix is needed to create an effective marketing. In this digital era, conventional marketing is no longer effective and efficient. With the existence of internet, companies will prefer the use of technology to promote their products to the market. Research model is proposed as follow:

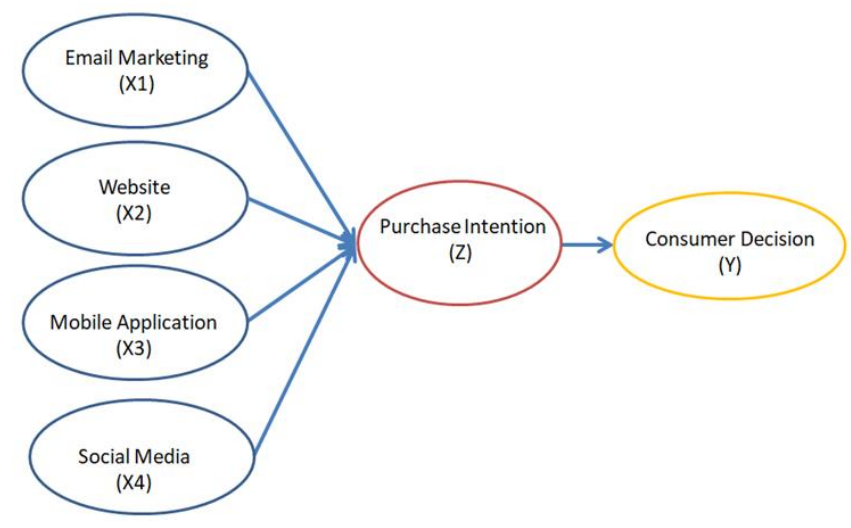

Figure 1 Research model on consumer decision

According to the study by Dehghani and Tumer [2], social media as one of digital marketing strategy has been proven to have a siginifacnt impact towards purchase intention. In addition, the study by Wee et al. [3] showed that purchase intention has significant effect towards consumer decision based on the Theory of Planned Behavior.

\section{LITERATURE REVIEW}

Marketing is about conversations, and the Internet has become a hub of conversations. The connected nature of the Internet allows us to follow and track these conversations, and provides entry points for all parties. Marketing on the internet has come into various shapes such as email marketing, online advertising, website, mobile applications and so on. Digital Marketing Communications refers to the use of new digital communication channels (or technologies/tools) to create an integrated, targeted and measurable communication process that helps companies acquire and retain customers while building a deeper relationship with them [4]. Other terms than 
digital marketing communications, are "e-marketing", "internet marketing" and "new media" [5].

Through previous research, we have realized that there are 4 main objectives of DMC such as: increase efficiency of communications, fosters customer relationship communications and interaction, creates awareness and helps build brands, and generates sales leads.

Through this research we aim to prove that digital marketing could give some effect towards purchase intention which will affect consumer decision/n to purchase the goods. Email marketing is a form of direct marketing that can render the best ROI of any eMarketing tactic which highly targeted and customisable, also cost effective. While social media can be use as integral part of an online marketing campaign. Social media is all about the ways that we create, connect and share online. Through social media, people can share things they like by bookmarking and aggregating, crowdsourcing and social networking. At the same time, website is a marketing tool used mainly to provide basic information needed to increase the revenue of a company/ an organization. A few factors that are crucial to the effectiveness and efficiency of a website includes standard convention (menus, logos, colours, layout, etc); information architecture (topics and categorization); sitemap; accessibility; and content. Therefore, when a website is built for users first and foremost with a good foundation, it will form the foundation of any emarketing to follow.

While website might be the benchmark of a good eMarketing, we can tailor the channel into web sites for mobile and also generate a mobile application. To create an effective mobile application, we need to keep it simple and stay away from the usage of tables as well as to keep images as small as possible. It is also very important to create something that has sufficient links in order not to cram too much content into a page. Note that most devices only able to display content in portrait mode and background image directive is bound to give problems on a number of devices. Last but not the least, be advised that JavaScript and Ajax might not be compatible to every device.

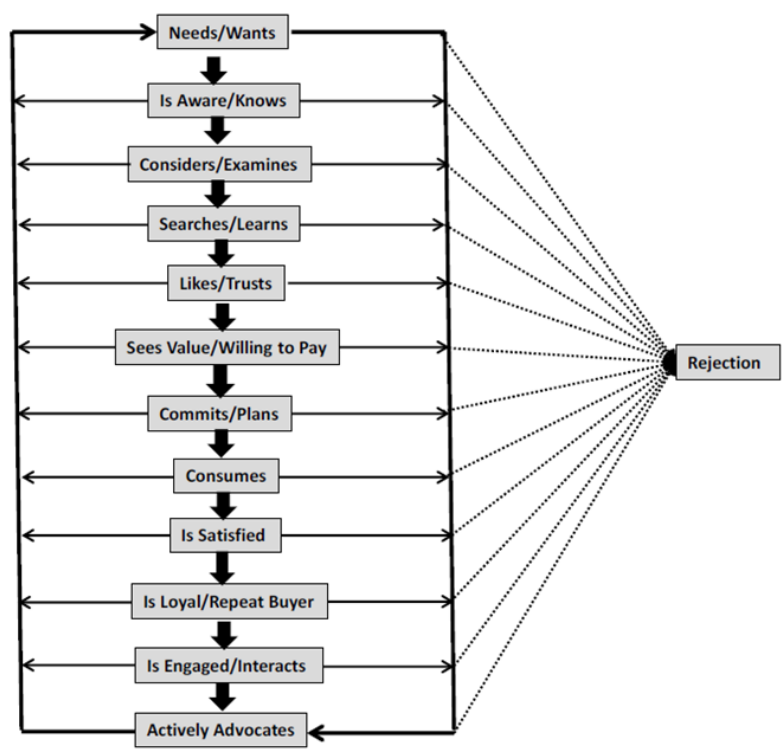

Figure 2. A dynamic, expanded consumer decision journey
Based on the figure above, it can be explained that consumer go through several processes before reaching the final decision. Marketers are increasingly attempting to coordinate all their online and offline communications activities. Recent research has provided much evidence as to how online and offline communications can interact by tapping into different stages of consumer decision journey [6][7]. Kumar et al. [8] found that firm-generated content in social media worked synergistically with both television advertising and e-mail marketing. Stephen and Galak [9] in studying microlending website Kiva, found that traditional earned media activity (e.g., press mentions in newspaper articles and on television programs) flowed from social media (e.g., posts made by consumers on online communities, social networking websites, or blogs), but not the other way around.

\section{METHODS}

As the leading MICE company in Indonesia, this research was conducted on Ismaya Live, that established Digital Marketing strategies such as newsletter, social media (Instagram, Facebook and Twitter), website and mobile applications. With the population of 192,000 followers on Instagram, 100 samples have been picked through simple random sampling method with error rate of $10 \%$. Data was collected through questionnaire with likert scale (1-6). The data then processed using multiple regressions linear.

\section{RESULTS}

The data was proven to be normally distributed and valid with assumptions that have been fulfilled. The data is then being processed further with multiple regression method with results as follow.

\section{A. Digital Marketing towards Purchase Intention}

Digital marketing strategy is proven to be the most effective strategy accumulating to $71.74 \%$ compared to $28.26 \%$ of other variables. Social media and website are the most significant with $p$ value of 0.0004 and 0.0017 respectively, followed by newsletter ( $\mathrm{p}$ value $=0.3228$ ), and mobile apps $(\mathrm{p}$ value $=0.3409)$.

\section{B. Purchase Intention towards Consumer Decision}

The effect of purchase Intention towards Consumer Decision is accumulating to $63.18 \%$ with p-value of zero which means that purchase intention has a very significant effect towards consumer decision.

\section{CONCLUSIONS}

The research concluded that Ismaya Live's social media \& website have significant effect towards purchase intention. In addition, purchase intention has been proven to have significant effect towards consumer decision. Future research could improve the range of digital marketing strategies in-line with future development.

\section{REFERENCES}

[1] International Meetings Review 2018 MICE industry set to hit $\$ 1.245$ billion in 2023 International Meetings Review retrieved r from http://www.internationalmeetingsreview.com/research/ mice-industry-set-hit-1245-billion-2023-104239 
[2] Dehghani M and Tumer M 2015 A research on effectiveness of Facebook advertising on enhancing purchase intention of consumers Computers in Human Behavior 49 597-600

[3] Wee C S, Md. Ariff M S, Zakuan N, Mohd Tajudin M N, Ismail K, and Ishak N 2014 Consumers perception, purchase intention and actual purchase behavior of organic food products Review of Integratuve Business and Economics Research 3(2) 378-397

[4] Mulhern F J 2009 Integrated marketing communications: From media channels to digital connectivity Journal of Marketing Communications 15(2-3) 85-101

[5] Hennig-Thurau T, Malthouse E C, Friege C, Gensler S, Lobschat L, Rangaswamy A, and Skiera B The impact of new media on customer relationships Journal of Service Research 13(3) 311-330
[6] Chang Y and Thorson E 2004 Television and web advertising synergies Journal of Advertising 33(2) 75-84

[7] Havlena W, Cardarelli R and De Montigny M 2007 Quantifying the isolated and synergistic effects of exposure frequency for TV, print, and internet advertising Journal of Advertising Research 47(3) 215-221

[8] Kumar A, Bezawada R, Rishika, Janakiraman R, and Kannan PK 2016 From social to sale: The effects of firmgenerated content in social media on customer behavior Journal of Marketing 80 7-25

[9] Stephen A T and Galak J 2012 The effects of traditional and social earned media on sales: A study of a microlending marketplace Journal of Marketing Research $49624-639$ 